\title{
PEMBENTUKAN PERATURAN PELAKSANA ZAKAT MENGURANGI PENGHASILAN KENA PAJAK DIHUBUNGKAN DENGAN UNDANG-UNDANG PAJAK PENGHASILAN
}

\author{
H. Atang Hermana \\ Advokat Muda Bidang Hukum Kepolisian Daerah Jawa Barat \\ E-mail: atang_hermana@yahoo.com
}

\begin{abstract}
The government of the Republic of Indonesia has its own regulation in the field of tax. Income tax is regulated in the Act No. 7 yeare 1983, then it was amended by Act No. 7 year 1991,furthermore it was amended by Act No. 10 year 1994, and the third amendment was the Act No. 17 year 2000. There are some replenisments in the Act No. 17 year 2000. One of these replenisments is intended to moslems. This replenisment is close related to tax payment which is paid by moslems and their tithe payment. The latest Act of Income Tax was amended by Act No. 36 year 2008 on the fourth amendment of Act No. 7 year 1983 on Income Tax. The steps of collecting tithe in the Act No. 23 year 2011 has a similarity to the steps of collecting tithe from the community, based on taxpayers report. The relationship between tax and tithe can be seen in article 22. Tax regulation and tithe management are close related in the field of tithe reduction on taxable income.
\end{abstract}

Keywords: tax; income; tithe; reduction; regulation.

\begin{abstract}
Abstrak
Bidang perpajakan, Negara Kesatuan Republik Indonesia memiliki pengaturan tersendiri. Pada pajak penghasilan pengaturannya terdapat pada Undang-Undang Nomor 7 Tahun 1983 yang diubah dengan Undang-Undang Nomor 7 Tahun 1991, kemudian diubah oleh Undang-Undang Nomor 10 Tahun 1994 dan perubahan yang ketiga pada Undang-Undang Nomor 17 Tahun 2000. Pada Undang-Undang Nomor 17 Tahun 2000 ada beberapa penambahan yang diantaranya adalah ditujukan bagi umat Islam. Penambahan tersebut terkait dengan pembayaran pajak yang dibayarkan oleh umat Islam dan pembayaran zakatnya. Undang-Undang Pajak Penghasilan tersebut terakhir diubah oleh Undang-Undang Nomor 36 Tahun 2008 tentang Perubahan Keempat Undang-Undang Nomor 7 Tahun 1983 tentang Pajak Penghasilan. Langkah pengumpulan zakat dalam Undang-Undang Nomor 23 Tahun 2011 tersebut memiliki kesamaan dengan langkah pengumpulan pajak dari masyarakat, yaitu berdasarkan pelaporan wajib pajak. Hubungan kedekatan antara pajak dan zakat terlihat dalam Pasal 22. Antar peraturan pajak penghasilan dan pengelolaan zakat memiliki keterkaitan yaitu berupa pengurangan zakat pada penghasilan kena pajak.
\end{abstract}

Kata Kunci: Pajak, Penghasilan, Zakat, Pengurangan, Pengaturan. 


\section{A. PENDAHULUAN}

Pengelolaan negara modern selalu didasarkan kepada prinsip-prinsip keterbukaan (transparansi), efektif dan efisien. Sebuah negara dengan sistem politiknya yang demokratis akan memberi ruang bagi partisipasi warga dalam seluruh proses politik yang berlangsung. Ketika partisipasi dan ruang publik untuk rakyat ditutup dan disumbat oleh mesinmesin politik, maka pengelolaan negara yang transparan sulit diharapkan. Dalam sejarah politik kenegaraan yang dibangun selama ini menempatkan penguasa dalam konteks yang istimewa, sementara rakyat berada dalam posisi kooptasi Negara, dengan kata lain rakyat tidak berdaya ketika berhadapan dengan penguasa negara. Kondisi politik demikianlah yang ingin dirubah oleh reformasi politik yang telah berlangsung, agar terjadi suatu pola hubungan antara rakyat dengan Negara (pemerintah) yang seimbang, rakyat memiliki sejumlah hak dan kewajiban yang harus ditunaikan sebagaimana Negara memiliki keharusan melindungi, mengayomi, dan mensejahterakan rakyatnya.

Negara modern diikat oleh berbagai perjanjian yang dibangun sebagai syarat terciptanya suatu keseimbangan sosial, ekonomi, politik dan hukum dalam suatu negara yang beradab. Perjanjian itu sendiri terkait dengan adanya hubungan timbal balik antara negara dengan masyarakat. Bahwa negara bisa ada karena ada rakyat dan rakyat sendiri membutuhkan pemimpin (negara) untuk mengatur kelangsungan hidup bersama agar beradab, tanpa adanya negara keadaban rasanya sulit tercipta.
Dalam mengikat hubungan yang saling membutuhkan itu, praktik politik negaranegara modern cenderung menerapkan pola yang lazim dipakai yakni negara memiliki sejumlah kewenangan yang absah kepada rakyat sebagaimana rakyat memiliki hak yang dituntut kepada negara. Dalam hal inilah, pajak menjadi media yang menghubungkan antara kepentingan negara dengan kepentingan rakyat dan pajak menjadi syarat lain bagi terciptanya suatu keseimbangan antara negara dan rakyat. Rakyat membayar pajak kepada negara dan sebagai jasa yang diperoleh rakyat adalah berupa perlindungan atas segala kepentingan umum, yaitu dengan memberikan hak-hak dasar warga negara secara proporsional seperti hak untuk hidup secara layak, hak kemanusian, hak untuk memperoleh keadilan, hak untuk menikmati kemerdekaan dan pembangunan, itulah hak-hak dasar yang diperoleh rakyat dari negara, sebab dengan memberikan hak-hak tersebutlah rakyat memperoleh keadilan. Esensi negara didirikan adalah untuk melindungi kepentingan bersama dan menjamin kesejahteraan sosial rakyat.

Pajak telah berfungsi sebagai sumber dana bagi pemerintah untuk membiayai pengeluaran-pengeluarannya. Salah satu pembiayaan Negara yang penting dalam hal ini adalah pembangunan sosial kemanusiaan, selain pembiayaan lainnya. Dalam teori Negara, bahwa Negara melakukan fungsinya untuk melayani kebutuhan masyarakat, tidak untuk kepentingan pribadi. Maka kepentingan umum didahulukan atas kepentingan pribadi dan golongan. Dengan luasnya tanggungjawab negara, maka negara 
membutuhkan dukungan finansial dari rakyat, kemudian negara membuat ketentuan yang akan dijadikan pijakan untuk mengimbangi ketimpangan sosial dalam masyarakat dengan pajak dengan membuat ketentuan untuk mewajibkan warga negara atas dasar kedaulatan menanggung pembiayaan sesuai dengan kemampuan.

Sekalipun pajak tidak begitu banyak dibahas dalam doktrin teologi Islam, tapi Islam pun memberikan beberapa ketentuan yang tegas mengenai hal ini terutama negara dalam kondisi yang tidak stabil. Dalam hal ini, Islam memberikan beberapa ketentuan kepada umat Islam agar membayar pajak sesuai dengan konteksnya harus memenuhi syarat seperti yang dikatakan oleh Yusuf AlQardawi ${ }^{1}$ : pertama, pajak itu benar-benar dibutuhkan dan negara tidak lagi memiliki sumber keuangan lain. Berdasarkan hal tersebut, negara boleh membebankan pajak kepada warga negara asalkan negara tersebut tidak lagi memiliki sumber keuangan yang dapat menutupi anggaran negara. Kedua, pembagian pajak yang adil. Dengan bersumber pada kekurangan sumber anggaran negara, maka rakyat wajib membayar pajak kepada negara agar diberikan secara adil. Ketiga, pajak hendaknya digunakan untuk kepentingan umat (rakyat) dan bukan untuk maksiat dan hawa nafsu. Pajak harus dikelola dengan prinsip kejujuran, keadilan dan sikap amanah para pemimpin negara, dengan begitu pajak akan memenuhi ketentuan yang disyaratkan yakni bukan untuk kepentingan pribadi, golongan, dan maksiat serta memperkaya diri para pejabat, melainkan untuk membangun infrastruktur sosial yang bisa dirasakan manfaatnya oleh rakyat banyak. Keempat, pajak sebelum dilakukan perlu memperoleh persetujuan para ahli dan cendekia. Sebelum sesuatu pajak dikenakan perlu memperoleh analisa, kajian, dan pendapat para ahli mengenai besar dan kecil pajak yang akan dipungut dari masyarakat.

Khusus dalam bidang perpajakan, Negara Kesatuan Republik Indonesia memiliki pengaturan tersendiri. Pada pajak penghasilan pengaturannya terdapat pada Undang-Undang Nomor 7 Tahun 1983 yang diubah dengan Undang-Undang Nomor 7 Tahun 1991, kemudian diubah oleh Undang-Undang Nomor 10 Tahun 1994 dan perubahan yang ketiga pada Undang-Undang Nomor 17 Tahun 2000. Pada Undang-Undang Nomor 17 Tahun 2000 ada beberapa penambahan yang diantaranya adalah ditujukan bagi umat Islam. Penambahan tersebut terkait dengan pembayaran pajak yang dibayarkan oleh umat Islam dan pembayaran zakatnya. Undang-Undang Pajak Penghasilan tersebut terakhir diubah oleh Undang-Undang Nomor 36 Tahun 2008 tentang Perubahan Keempat Undang-Undang Nomor 7 Tahun 1983 tentang Pajak Penghasilan.

$$
\text { Pada Undang-Undang pajak }
$$
penghasilan bagi umat Islam yang memiliki penghasilan dapat membayar zakatnya dan pembayaran zakat tersebut dapat

1 Yusuf Qardawi, Hukum Zakat, Pustaka Lentera Antar Nusa, terjemahan oleh Salman Harun, Didin Hafiuddin, Hasanudin, 2004, hlm. 1079 - 1085. 
dikurangkan pada pembayaran pajak atas penghasilan yang sama. Dengan adanya ketentuan tersebut, maka umat Islam terhindar dari pembayaran berganda pada penghasilan yang sama. Sebelum adanya perubahan Undang-Undang Pajak Penghasilan terakhir pada tahun 2008, maka umat Islam terkena pembayaran pajak dan zakat pada penghasilan yang sama. Umat Islam disatu sisi membayar zakat yang merupakan kewajiban bagi umat Islam tetapi disisi lain juga harus membayar pajak sebagai kewajiban bagi seorang warga negara.

Di Indonesia pemberlakuan pajak harus didasarkan pada undang-undang, artinya bahwa setiap pemberlakuan pajak harus berdasarkan undang-undang. Dalam hierarki peraturan perundang-undangan bentuk undang-undang merupakan peraturan pelaksana dari UndangUndang Dasar 1945, hierarki peraturan perundang-undang dapat kita lihat dalam Undang-Undang Nomor 12 Tahun 2012 tentang Pembentukan Peraturan Perundang-undangan.

Pada penulisan ini penulis lebih menitikberatkan pada pembayaran zakat yang dapat mengurangi penghasilan kena pajak. Pada Undang-Undang Nomor 17 Tahun 2000 yang terakhir telah diubah oleh Undang-Undang Nomor 36 Tahun 2008 tentang Perubahan Keempat Atas UndangUndang Nomor 7 Tahun 1983 tentang Pajak Penghasilan dapat kita temukan bahwa zakat dapat mengurangi penghasilan kena pajak, tetapi untuk melaksanakan hal tersebut, maka diperlukan suatu peraturan pelaksanaannya.

Membaca latar belakang di atas, maka terdapat permasalahan antara lain:
1. Apakah cara pembayaran zakat agar dapat mengurangi penghasilan kena pajak, sebagaimana tercantum dalam Undang-Undang Nomor 36 Tahun 2008 tentang Perubahan Keempat Undang-Undang Nomor 7 Tahun 1983 tentang Pajak Penghasilan telah dilaksanakan?

2. Apakah peraturan mengenai pajak penghasilan dalam hal zakat yang dapat mengurangi penghasilan kena pajak telah sesuai dengan peraturan tentang zakat?

3. Adakah hambatan-hambatan dalam pembentukan peraturan pelaksana pengurang penghasilan kena pajak?

\section{B. PEMBAHASAN}

\section{Zakat sebagai Pengurang Pajak Penghasilan sebagai Solusi bagi Umat Islam}

Negara Indonesia bukan negara sekuler dan bukan pula negara agama (bukan negara Islam) walaupun sila pertama Pancasila adalah Ketuhanan Yang Maha Esa, maka sila pertama tersebut apabila dilihat dari sudut hukum Islam dapat dipahami identik dengan tauhid yang merupakan inti dari ajaran Islam. Dengan satu pengertian bahwa dalam ajaran Islam memberikan toleransi kebebasan dan kesempatan yang seluasluasnya bagi pemeluk-pemeluk lainnya untuk melaksanakan ajaran agama masing-masing.

Bagi Islam, kehidupan ini harus dijalankan secara seimbang, oleh karena itu dalam kehidupan di dunia ini kalaupun ada yang miskin dan kaya itu sudah menjadi hukum Allah, dengan itulah Allah akan menguji umat-Nya. Mereka yang 
memiliki kekayaan, apakah menggunakan menurut kehendak Islam atau tidak, apakah zakatnya, sedekah, infak dan sebagainya telah ditunaikan atau belum? Mereka yang memiliki kelebihan harta harus menggunakannya di jalan yang dibenarkan oleh agama, mereka yang memiliki kekayaan tidak hanya kekayaan itu berputar dan beredar di kalangan orang kaya, tetapi harus merata antara sesama umat. Dalam hal ini, zakat menjadi wahana bagi proses pemerataan harta (distribusi kesejahteraan), antara mereka yang kaya dengan mereka yang miskin. Kelompok masyarakat yang memiliki kelebihan harta harus mengeluarkan kewajiban dari harta itu, karena kewajiban itu merupakan haknya orang miskin, mustad'afin atau kaum dhu'afa.

Tampaknya masalah zakat ini belum banyak memperoleh perhatian dari kalangan politisi dan birokrasi, oleh karena mereka belum melihat peluang-peluang tertentu bagi mereka dari aspek zakat ini. Para politisi hanya memikirkan kepentingan mereka sendiri, sekalipun kekuasaan dan kedudukan yang disandangnya berkat kepiawaian mereka dalam mempengaruhi rakyat agar rakyat dapat memilihnya untuk diwakili. Sebagai politisi, mereka memberikan janji dan harapan itu masih kurang meyakinkan rakyat, maka dikuatkan dengan ayat dan hadist, masih kurang juga dicari pijakan argumentasi teoritik agar dapat meyakinkan rakyat. Tetapi nyatanya setelah mereka berkuasa terutama dari politisi ideologis belum juga maksimal memberikan perhatiannya kepada umat dan rakyat sebagai wakil umat Islam mestinya politisi Islam harus menggali nilai-nilai Islam dalam rangka memenuhi sebagian dari janji politiknya untuk mensejahterakan rakyat.

Para politisi harus memikirkan realitas masyarakat yang umumnya menganut agama Islam, sungguhpun soal teologi keagamaan bukanlah hal yang perlu diperdebatkan, tetapi untuk menggali potensi ekonomi umat haruslah pula digunakan pendekatan teologi sosial yang dapat memberikan kepercayaan rakyat kepada negara. Zakat menurut hemat penulis berpotensi besar untuk memberikan harapan kepada rakyat dalam rangka mereka keluar dari kemelut sosial, ekonomi dan politik yang hingga kini masih terus dirasakan oleh bangsa Indonesia. Zakat secara ekonomi dapat menjadi pendorong yang kuat bagi investasi, dengan zakat yang terkumpul dari umat kemudian dikelola dengan rasa tanggung jawab yang tinggi, tentu menjadi modal besar bagi penciptaan lapangan kerja baru yang akan menampung sejumlah tenaga kerja yang Insya Allah akan dapat mengurangi sekitar 2,5\% dari total ratio penduduk yang menganggur setiap tahunnya.

Pada ajaran Islam salah satu kewajiban bagi seseorang adalah membayar zakat. Zakat bukanlah merupakan sumber pendapatan negara melainkan merupakan sumber pendapatan bagi umat Islam yang diperoleh dari wajib zakat (muzaki) diperuntukan bagi para penerima zakat (mustahik). Berbeda dengan pajak, pajak adalah merupakan salah satu sumber pendapatan negara yang dipergunakan untuk membiayai roda pemerintahan dan membangun kebutuhan sarana dan prasarana umum. Walaupun Indonesia 
bukan negara Islam, tetapi tidak ada salahnya jika pemerintahan ikut mengatur kepentingan umat Islam dalam menjalankan syariat Islam khususnya zakat.

Merupakan kewajiban bagi negara kesejahteraan seperti Indonesia, untuk mensejahterakan warganya. Pemerintah melalui Undang-Undang Nomor 38 Tahun 1999 Tentang Pengelolaan Zakat telah mengatur bagaimana caranya agar dapat menghimpun potensi dana umat Islam dari sektor zakat secara profesional, dengan dana tersebut diharapkan dapat mensejahterakan umat Islam sebagai warga negara. Selain itu Undang-Undang tersebutjuga sebagai bentuk kebijakan dan pengaturan dari pemerintah dalam segi pengelolaan zakat dalam memanfaatkan dan pendayagunaan zakat dengan sebaikbaiknya.

Pada dasarnya umat Islam diwajibkan membayar zakat. Hal ini tercantum dalam rukun ketiga dari lima rukun Islam yang merupakan tiang agama. Zakat yang telah terkumpul kemudian disalurkan dalam jalur-jalur yang telah ditetapkan. Para pemberi dan penerima zakat tersebut berada dalam lingkaran atau kaitan dengan ukhuwah islamiyah.

Zakat sebagai ketentuan dari ajaran Islam yang diwajibkan oleh Allah SWT. Pada harta orang Islam sebagai bentuk rasa syukur. Ada beberapa jenis kekayaan yang disebutkan oleh Al-Qur'an yang wajib dikeluarkan zakatnya sebagai hak Allah² adalah: a. Harta berupa emas dan perak

b. Tanaman dan buah-buahan

c. Usaha

d. barang-barang tambang yang dikeluarkan dari perut bumi

Pengertian kekayaan tersebut adalah bahwa sesuatu yang berwujud ${ }^{3}$ dan itulah yang terkena kewajiban zakat. Kekayaan yang dimiliki oleh seseorang tentu tidak semua langsung terkena zakat, tetapi ada batasan-batasan tentang sifat kekayaan yang wajib kena zakat atau syaratsyaratnya antara lain ${ }^{4}$ :

a. Milik penuh

Bahwa kekayaan itu harus penuh berada dibawah kontrol dan dalam kekayaannya ditetapkannya syarat tersebut di atas karena kepemilikan adalah nikmat yang besar.

b. Berkembang

Kekayaan itu dikembangkan dengan sengaja atau mempunyai potensi berkembang. Pengertian berkembang menurut bahasa sekarang adalah bahwa sifat kekayaan itu memberikan keuntungan bunga atau pendapatan keuntungan investasi.

c. Cukup nisab

Ketentuan bahwa kekayaan yang terkena kewajiban zakat harus sampai nisab disepakati oleh para alim ulama kecuali hasil pertanian, buah-buahan dan logam mulia.

d. Lebih dari kebutuhan biasa

Kekayaan yang sudah berkembang harus lebih daripada kebtuhan rutin. Artinya bahwa yang terkena zakat 
adalah kekayaan yang telah dikurangi biaya rutin sehari-hari.

e. Bebas dari hutang.

Pemilikan sempurna yang dijadikan persyaratan wajib pajak dan harus lebih dari kebutuhan primer dan juga cukup nisab yang bebas dari hutang. Bila pemilik kekayaan masih punya hutang yang mengurangi nisab maka zakat tidak diwajibkan.

\section{f. Berlaku setahun}

Pemilikan terhadap kekayaan tersebut harus sudah dua belas bulan qomariah. Persyaratan ini hanya terhadap ternak, uang dan harta benda dagang. Tetapi hasil pertanian, buah-buahan, madu, logam mulia dan harta karun tidak disyaratkan setahun.

Seorang umat Islam yang telah memiliki kekayaan yang tercantum di atas dan juga memenuhi persyaratanpersyaratannya maka wajib mengeluarkan zakat. Dengan dikeluarkannya UndangUndang Nomor 38 Tahun 1999 tentang Pengelolaan Zakat diharapkan zakat dapat dikelola dengan baik dan tepat mengenai sasaran zakat yang diberikan kepada yang dikenal dengan 8 asnab atau golongan yaitu fakir, miskin, orang yang memerdekakan budak, amil zakat, muallaf, orang yang berhutang, fisabilillah dan ibnu sabil.

Dalam Undang-Undang Nomor 23 Tahun 2011 tidak disebutkan bahwa pengelolaan zakat dilakukan oleh negara, tetapi oleh badan amil zakat yang dibentuk oleh pemerintah. Tugasnya hanya menerima dan menampung zakat yang dibayarkan oleh rakyat dan tidak memiliki kewenangan untuk menarik zakat secara paksa. Pengelolaan tersebut sebagaimana dimaksud dalam Pasal 1 ayat (1) meliputi "kegiatan perencanaan, pengorganisasian, pelaksanaan, dan pengawasan terhadap pengumpulan dan pendistribusian serta pendayagunaan zakat". Lembaga amil menurut Pasal 17 adalah "institusi pengelolaan zakat yang sepenuhnya dibentuk atas prakarsa masyarakat dan oleh masyarakat", sekalipun begitu dalam Pasal 19 disebutkan "institusi ini bertanggung jawab kepada pemerintah sesuai dengan tingkatannya".

Berdasarkan pada beberapa pasal yang dikutip diatas, maka zakat masih dikelola oleh pihak swasta yang sekalipun mekanisme kerja dan pembinaan masih dalam kontrol pemerintah. Dalam hal ini, tidaklah suatu kewajiban yang dibebankan kepada umat Islam untuk membayar zakat, melainkan pengumpulan zakat dilakukan oleh lembaga berdasarkan kesukarelaan warga tanpa adanya paksaan dari negara. Dalam Pasal 34 disebutkan pula, bahwa pemerintah Republik Indonesia berkewajiban memberikan perlindungan, pembinaan dan pelayanan karena pengelolaan zakat menyangkut hak dan kewajiban sebagian besar warga negara dan kepastian hukum sesuai UndangUndang Dasar 1945. Zakat dalam konteks ini berhubungan dengan hajat hidup orang banyak sebagaimana posisi pajak yang menjadi sentra dari pembiayaan proyek pemerintah, yang berbeda adalah pajak langsung dibawah Departemen Keuangan, sedangkan zakat dikelola oleh swasta yang kewajiban negara hanyalah sebatas pembinaan dan perlindungan seadanya.

Langkah pengumpulan zakat dalam Undang-Undang Nomor 23 Tahun 2011 tersebut memiliki kesamaan dengan langkah pengumpulan pajak dari 
masyarakat, yaitu berdasarkan pelaporan wajib pajak. Hubungan kedekatan antara pajak dan zakat terlihat dalam Pasal 22 Undang-Undang Nomor 23 Tahun 2011 yang menyebutkan bahwa pembayaran zakat kepada badan yang ditunjuk oleh pemerintah dapat mereduksi pajak. Ini dimaksudkan sebagaimana pejelasan Pasal 22 tersebut "agar wajib pajak tidak dikenakan beban ganda, yakni kewajiban membayar zakat dan pajak. Kesadaran membayar zakat dapat memacu kesadaran membayar pajak". Pajak dalam konteks ini tetap ditekankan kepada kewajiban warga negara untuk membayarkan kepada negara, sekalipun kaum muslimin telah membayar zakat kepada lembaga zakat seperti BAZ dan LAZ juga dibebankan membayar pajak, sesuai dengan perintah hukum negara dan juga perintah agama. Hal ini sejalan dengan Sabda Rasulullah SAW seperti diriwayatkan oleh Imam Daaruquthni dari Fatimah Binti Qayis "Sesungguhnya dalam harta ada kewajiban lain, diluar zakat". Kemudian hadist lain menyebutkan "Nabi SAW ditanya tentang zakat, beliau bersabda, 'sesungguhnya dalam harta itu ada kewajiban lain diluar zakat', kemudian Nabi SAW membaca AlQur'an surat Al-Baqarah ayat 177"5.

Kewajiban membayar pajak selain zakat dapat disebutkan untuk untuk memperoleh gambaran yang jelas agar umat Islam dapat menunaikan kewajiban ganda tersebut, selain disebutkan dalam QS Al-Baqarah ayat 177 “.....Nabi-nabi dan memberikan harta yang dicintainya kepada kerabatnya, anak-anak yatim, orangorang miskin, musafir (yang memerlukan pertolongan), hamba sahaya, mendirikan shalat, dan menunaikan zakat; dan orangorang yang menepati janjinya apabila ia berjanji, dan orang-orang yang sabar dalam kesempitan, penderitaan dan dalam peperangan...... Dalam berbagai tafsir para ulama, bahwa kaum muslimin setelah menunaikan zakat, juga dihadapkan pada berbagai kebutuhan dan keperluan yang harus ditanggulangi, maka wajib mengeluarkan harta untuk keperluan tersebut ${ }^{6}$. Harta untuk keperluan itulah yang disebut dengan pajakyang diatur oleh negara, dimana pemimpin telah dipilih oleh rakyat menurut ukuran dan standar yang telah disepakati dalam komunitas politik dan didasarkan kepada nilai-nilai budaya bangsa yang eksis.

Selain mengeluarkan undang-undang tentang pengelolaan zakat tersebut pemerintah mengeluarkan juga undangundang di bidang perpajakan. Dengan mengeluarkan undang-undang tentang pajak penghasilan yang berkaitan dengan zakat. Zakat yang bisa dikaitkan dengan pajak penghasilan adalah zakat penghasilan. Penghasilan ini merupakan salah satu kekayaan. Penghasilan yang dapat dikenakan zakat haruslah memenuhi syarat-syarat tersebut di atas. Pajak penghasilan baru dapat dikaitkan dengan zakat adalah dimulai pada Undang-Undang Nomor 17 Tahun 2000 yang merupakan perubahan ketiga atas Undang-Undang Nomor 7 Tahun 1983 tentang Pajak

\footnotetext{
5 Edi Slamet Irianto - Syarifudin Jurdi, Politik Perpajakan Membangun Demokrasi Negara, UII Press, Yogyakarta, 2005, hlm. 162.

6 Ibid., hlm. 163.
} 
Penghasilan. Pada perubahan ini lah zakat dapat mengurangi penghasilan kena pajak sebagaimana dimaksud dalam Pasal 9 ayat (1) huruf g. Artinya adalah bahwa zakat baru bisa mengurangi penghasilan kena pajak mulai tahun 2000 dengan berlakunya undang-undang tersebut. Undang-undang Pajak Penghasilan mengalami perubahan keempat dengan terbitnya UndangUndang Nomor 36 Tahun 2008.

Pajak merupakan peralihan kekayaan dari rakyat ke negara dalam hal ini kas negara untuk membiayai pengeluaran negara. Salah satu pajak di Indonesia adalah pajak penghasilan dan dalam Undang-Undang Nomor 36 Tahun 2008 kita dapatkan pengertian dari penghasilan yaitu setiap tambahan kemampuan ekonomis yang diterima oleh wajib pajak yang dapat dipakai untuk konsumsi atau untuk menambah kekayaan wajib pajak. Tujuan dari dibentuknnya Undang-Undang Nomor 36 Tahun 2008 Tentang Perubahan Keempat Undang-Undang Nomor 7 Tahun 1983 tentang Pajak Penghasilan adalah:

a. Meningkatkan keadilan pajak.

b. Memberikan kemudahan kapada wajib pajak.

c. Memberikan kesederhanaan administrasi perpajakan.

d. Memberikan kapastian hukum, konsistensi dan transparansi.

e. Menunjang kebijakan pemerintah dalam rangka meningkatkan daya saing dalam menarik investasi langsung di Indonesia baik penanaman modal asing maupun penanaman modal dalam negeri di bidang-bidang usaha tertentu dan daerah-daerah tertentu yang mendapatkan prioritas.

Undang-undang pajak penghasilan yang baru memiliki fungsi regulern atau fungsi mengatur. Fungsi mengaturnya yaitu dengan digunakannya zakat sebagai pengurang penghasilan kena pajak maka diharapkan masyarakat atau rakyat yang memeluk agama Islam mau meningkatkan pembayaran zakatnya.

Zakat dapat mengurangi penghasilan kena pajak menurut undang-undang tentang pengelolaan zakat dan undangundang tentang pajak penghasilan tersebut di atas dapat dilakukan. Tetapi tentu saja dengan adanya kedua undang-undang tersebut tidak serta merta dapat dilaksanakan tanpa adanya peraturan pelaksana. Meskipun dalam RPJMN menyatakan bahwa sebagai penghambat pelaksanaan undangundang adalah kebiasaan menunggu peraturan pelaksanaannya. Khususnya pada undang-undang pengelolaan zakat dan pajak penghasilan masih memerlukan peraturan pelaksana. Peraturan pelaksana ini diperlukan karena pada zakat yang dapat mengurangi penghasilan kena pajak menyangkut dua departemen yaitu Departemen Keuangan dan Departemen Agama.

Zakat yang dapat mengurangi penghasilan kena pajak merupakan salah satu solusi bagi umat Islam. Sebelum terbitnya Undang-Undang Nomor 17 Tahun 2000 tentang Perubahan Ketiga Undang-Undang Nomor 7 Tahun 1983 tentang Pajak Penghasilan, maka umat Islam wajib membayar pajak merupakan kewajiban sebagai warga negara. Selain itu umat Islam sebagai warga negara juga wajib membayar zakat sehingga terkena dua kali pungutan atau pungutan berganda. Sejak dikeluarkannya Undang- 
Undang Nomor 17 Tahun 2000, maka pungutan tersebut dapat diminimalisir yaitu zakat dapat mengurangi penghasilan kena pajak

Zakat yang mengurangi penghasilan kena pajak setidaknya dapat menyelesaikan sebagian permasalahan bagi umat Islam. Hal ini disebabkan karena zakat tidak mengurangi pajak penghasilan hanya mengurangi penghasilan kena pajak atau lebih disamakan dengan biaya. Zakat dapat mengurangi penghasilan kena pajak jika zakat dibayarkan pada BAZ dan LAZ ini tercantum dalam undang-undang pajak penghasilan.

Pada kenyataaanya khusus untuk wilayah Kota Bandung, zakat hanya dapat mengurangi penghasilan kena pajak jika pembayarannya dilakukan pada BAZ. Pengurangan zakat pada penghasilan kena pajak tidak dapat dilakukan jika pembayaran zakat dilakukan di LAZ. Dalam penelitian ini khususnya pada "Rumah Zakat", zakat yang dibayarkan pada "Rumah Zakat" selama ini tidak terdapat bahwa zakat yang dibayarkan untuk mengurangi penghasilan kena pajak. Apabila pembayaran zakat ke LAZ dan zakat tersebut diharapkan dapat mengurangi penghasilan kena pajak untuk saat ini belum diketemukan, kecuali hal ini baru terjadi pada instansi Pemerintah Daerah khususnya di Kota Bandung.

Ada beberapa kendala yang memungkinkan hal ini terjadi antara lain:

a. Pada kasus dimana seharusnya zakat dapat mengurangi penghasilan kena pajak karena telah terdapatnya undang-undang yang mengatur baik Undang-Undang Nomor 17 Tahun 2000 serta perubahannya yaitu
Undang-Undang Nomor 36 Tahun 2008 tentang Pajak Penghasilan dan juga Undang-Undang Nomor 38 Tahun 1999 tentang Pengelolaan Zakat. Pada peraturan tersebut ditemukan peraturan pelaksana antara lain Keputusan Menteri Agama Nomor 581 Tahun 1999 tentang Pelaksanaan Undang-Undang Nomor 38 Tahun 1999. Peraturan pelaksana lainnya adalah diatur oleh pemerintah daerah tersendiri. Khusus di Kota Bandung diatur dengan peraturan-peraturan sebagai berikut:

1) Peraturan Daerah Kota Bandung Nomor 30 Tahun 2002 tentang Pengelolaan Zakat, Infaq dan Shadaqah.

2) Keputusan Walikota Bandung Nomor 279 Tahun 2004 tentang Teknis Pengelolaan Zakat, Infaq dan Shadaqah.

3) Keputusan Walikota Bandung Nomor 451.121/Kep.069-Huk/ 2006 tentang Pembentukan dan Pengurus BAZ Kota Bandung Periode 2006-2009.

Pada penelitian ini juga penulis menemukan peraturan pelaksana yang dikeluarkan oleh Departemen Keuangan, yaitu Keputusan Direktur Jenderal Pajak Nomor: Kep-163/ $\mathrm{Pj} / 2003$, yang ditetapkan tanggal 10 Juni 2003 tentang Perlakuan Zakat atas Penghasilan Dalam Perhitungan Kena Pajak Penghasilan. Menurut penulis peraturan pelaksana yang ada sekarang kurang memadai, oleh karena itu diperlukan peraturan yang lebih tinggi dari peraturan pelaksana tersebut antara lain berbentuk 
peraturan pemerintah sehingga diharapkan peraturan pemerintah tersebut dapat mengikat dan dipatuhi oleh warga negara.

b. Dengan peraturan yang telah ada sekarang belum semua pembayaran zakat dapat mengurangi penghasilan kena pajak. Zakat yang dapat mengurangi penghasilan kena pajak dapat dilakukan di kalangan Pemerintah Kota Bandung. Hal ini dapat dilihat pada kwitansi sebagai tanda terima bukti setor. Tanda terima tersebut sesuai dengan Peraturan Daerah dan Keputusan Walikota Bandung yang menyatakan bahwa bukti setor harus memuat sebagai berikut:

1) Nama alamat Badan Pengelola Zakat.

2) Nomor pendaftaran badan pengelola zakat dari walikota.

3). Nama, alamat, nomor pokok wajib zakat dan nomor pokok wajib pajak.

4) Jumlah zakat yang disetorkan.

5) Tanda tangan, nama, jabatan, petugas pada pengelola zakat.

Sementara pada Keputusan

Direktur Jenderal Pajak, bahwa bukti setor harus memuat sekurangkurangnya:

1) Nama lengkap wajib pajak.

2) Alamat jelas wajib pajak.

3) Nomor pokok wajib pajak.

4) Jenis penghasilan yang dibayar zakat.

5) Besarnya zakat penghasilan dan bulan / tahun perolehannya.

6) Besarnya penghasilan.

7) Besarnya zakat penghasilan.
Bukti setor itu dapat disertakan pada surat pemberitahuan pajak waktu akan membayar pajak. Dengan adanya perbedaan hal-hal apa yang tercantum dalam bukti setor tersebut mengakibatkan terjadinya suatu hambatan. Hambatan tersebut antara lain zakat yang dibayar tidak dapat mengurangi penghasilan kena pajak. Pembayaran zakat yang bukti setornya sesuai dengan yang diinginkan oleh Keputusan Direktur Jenderal Pajak yang memungkinkan zakat dapat mengurangi penghasilan kena pajak.

c. Zakat yang dapat mengurangi penghasilan kena pajak baru dapat dilakukan dilingkup pemerintahan Kota Bandung. Hal ini disebabkan data-data yang diperlukan oleh pihak pajak terdapat pada bendahara kantor. Kendala-kendala tersebut di atas bisa diatasi dengan melalui penegakan hukum. Disamping itu juga diperlukan kesadaran dari warga negara dan khususnya kesadaran dari umat Islam, sehingga diharapkan tercapai optimalisasi dalam pengelolaan zakat.

\section{Peningkatan Zakat sebagai Pengurang Penghasilan Kena Pajak}

Sebagai bagian yang penting dari ajaran Islam, zakat telah ditegaskan oleh Allah sebagai ajaran agama yang wajib ditunaikan oleh mereka yang memiliki kelebihan harta. Dalam konteksnya yang empirik, zakat dan muzakki yang dikeluarkan di Indonesia setiap tahunnya belumlah dapat dijadikan acuan atau parameter dalam mengukur kondisi ekonomi bangsa, sebabnya zakat bersifat sukarela dan tidak diwajibkan oleh 
undang-undang negara, hal ini berbeda dengan pajak yang telah ditetapkan besar kecilnya yang harus dibayarkan oleh para wajib pajak kepada negara dalam setiap tahun. Sedangkan zakat kalau dijadikan landasan untuk menilai atau mengukur kondisi ekonomi umat belum dapat dijadikan dasar. Alasannya para pihak yang memiliki kewajiban mengeluarkan zakat atas hartanya sejauh ini belum memiliki dasar hukum dan institusi yang kuat sebagai pemaksa mereka untuk mengeluarkan zakat, seperti halnya Undang-undang dan institusi pajak.

Pada dasarnya umat Islam diwajibkan membayar zakat, bahkan agama Islam menjadikan zakat sebagai rukun ketiga dari lima rukun Islam. Zakat itu wajib dimanfaatkan pada jalur-jalur yang telah ditetapkan. Dalam keadaan tertentu Islam membenarkan pemungutan selain zakat seperti pajak. Tetapi pajak tidaklah dapat menggantikan zakat karena keduanya terdapat perbedaan.

Di samping perbedaan tersebut terdapat juga persamaan antara zakat dan pajak antara lain:

a. Bersifat wajib dan mengikat atas harta penduduk suatu negeri, apabila melalaikannya terkena sanksi.

b. Zakat dan pajak harus disetorkan pada lembaga resmi agar tercapai efisiensi penarikan keduanya dan alokasi penyalurannya. Dalam pemerintahan Islam, zakatdan pajak dikelola oleh negara.

c. Tidak ada ketentuan memperoleh imbalan materi tertentu di dunia.

d. Dari sisi tujuan ada kesamaan antara keduanya yaitu untuk menyelesaikan problem ekonomi dan mengentaskan kemiskinan yang terdapat di masyarakat.

Pada dasarnya zakat dan pajak hukumnya sama-sama yaitu wajib, yang menjadi perbedaanya adalah kewajiban zakat berdasarkan agama sedangkan pajak berdasarkan kebijakan pemerintah. Pajak merupakan salah satu sumber pendapatan untuk mengisi kas negara, sedangkan zakat bukan merupakan sumber pendapatan negara.

Pemanfaatan dan mendayagunakan zakat dengan sebaik-baiknya diperlukan kebijakan dalam bentuk peraturan dari pemerintah dalam segi pengelolaan zakat. Di Indonesia pengaturan mengenai pengelolaan zakat dibentuk melalui Undang-Undang Nomor 23 Tahun 2011. Undang-undang tentang pengelolaan zakat ini memiliki keterkaitan dengan undangundang tentang pajak penghasilan yaitu Undang-Undang Nomor 17 Tahun 2000 dan perubahan keempatnya yaitu UndangUndang Nomor 36 Tahun 2008.

Zakat memiliki potensi yang cukup besar dalam meningkat perekonomian khususnya umat Islam. Khusus zakat dapat dikelola oleh umat Islam melalui lembaga pemerintah ataupun lembaga-lembaga non pemerintah atau lembaga amil zakat yang independen. Pemerintah juga memberikan insentif kepada lembagalembaga amil zakat yang didirikan secara independen. Hal ini dapat kita lihat pajak penghasilan memiliki fungsi regulern dengan tidak mengenakan pajak penghasilan terhadap penghasilan yang diterima oleh lembaga tersebut.

Pemerintah dengan kewenangannya dalam pemungutan pajak dan turut mengatur dalam hal mendorong umat 
Islam untuk membayar zakat dan bagi pengelola zakat diharapkan dapat bekerja secara profesional demi kemaslahatan umat Islam. Zakat merupakan faktor yang dapat meningkatkan potensi ekonomi dan kehidupan umat Islam ${ }^{7}$. Oleh karena itu diperlukan adanya kesadaran umat Islam untuk mendukung terselenggaranya pengelolaan zakat serta pelaksanaan pajak. Agar zakat dapat meningkatkan potensi ekonomi maka undangundang pengelolaan zakat mengatur pendayagunaan dan penerimaan zakat.

Walaupun Indonesia bukan negara Islam tidak ada salahnya bila pemerintah ikut mengatur kepentingan umat Islam dalam menjalankan syari'at Islam khususnya zakat, bahkan merupakan kewajiban bagi negara kesejahteraan (welfare state).

Sebagai jalan keluar agar potensi pambayaran zakat sebagai pengurang penghasilan kena pajak, maka dapat disimpulkan adalah pembayaran zakat haruslah dilakukan pada badan amil zakat, baik itu yang didirikan oleh pemerintah atau lembaga amil zakat yang didirikan secara independen. Pembayaran zakat yang dilakukan pada BAZ dan LAZ. Badan amil zakat yang didirikan atau pun lembaga yang didirikan secara independen harus memperhatikan undang-undang pengelolaan zakat sehingga sebagai amil zakat mampu mempertanggungjawabkan segala keuangannya kepada setiap umat Islam serta pemerintah.
Zakat yang dapat mengurangi penghasilan kena pajak juga dapat ditingkatkan dengan membentuk peraturan pelaksana, peraturan pelaksana tersebut tentu harus sesuai dengan hierarki peraturan perundang-undang yang ada. Dengan terbentuknya peraturan sebagai produk hukum, terbentuknya peraturan memberikan kepastian hukum. Hubungan hukum dan kepastian hukum tidaklah bersifat mutlak ${ }^{8}$. Hukum tidak serta merta menciptakan kepastian hukum yang benar, bersifat mutlak adalah hukum menciptakan kepastian peraturan artinya bentuk peraturan perundang-undangan.

Begitu suatu undang-undang dikeluarkan, maka pada saat yang sama muncul kepastian peraturan. Sebaliknya dipisahkan kehadiran kepastian peraturan dan kepastian hukum, agar kita dapat lebih seksama dalam masalah kepastian hukum. Kepastian hukum khususnya dalam hal zakat dapat mengurangi penghasilan kena pajak masih perlu ditinjau kembali. Kepastian hukum merupakan suatu keadaan yang memerlukan usaha dan perjuangan serta tidak datang secara otomatis begitu undang-undang berlaku. Oleh karena itu kepastian hukum itu lebih merupakan fenomena psikologi, sosiologi dan budaya ${ }^{9}$.

Pembentukan peraturan UndangUndang Nomor 17 Tahun 2000 serta perubahan terakhirnya yaitu UndangUndang Nomor 36 Tahun 2008 dan Undang-Undang Nomor 38 Tahun 1999,

\footnotetext{
Syofrin Syofyan - Asyhar Hidayat, Hukum Pajak dan Pemasalahannya, PT Refika Aditama, Bandung, 2004, hlm. 47.

8 Satjipto Rahardjo, Biarkan Hukum Mengalir, catatan kritis tentang pergulantan manusia dan hukum, Kompas, Jakarta, 2007, hlm. 78.

9 Ibid., hlm. 80.
} 
serta peraturan pelaksananya ada baiknya melihat asas-asas peraturan undangundang yaitu berdasarkan sila-sila Pancasila dan asas-asas dalam UndangUndang Nomor 12 tahun 2011 tentang Pembentukan Peraturan Perundangundangan.

Adanya perubahan Undang-Undang Dasar Negara Republik Indonesia Tahun 1945, khususnya Pasal 20 ayat (1) yang menentukan bahwa Dewan Perwakilan Rakyat memegang kekuasaan membentuk Undang-Undang, maka berbagai Peraturan Perundang-undangan tersebut di atas sudah tidak sesuai lagi. Dengan demikian diperlukan Undang-Undang yang mengatur mengenai Pembentukan Peraturan perundang-undangan, sebagai landasan yuridis dalam membentuk Peraturan perundang-undangan baik di tingkat pusat maupun di tingkat daerah, sekaligus mengatur secara lengkap dan terpadu baik mengenai sistem, asas, jenis dan materi muatan Peraturan Perundangundangan, persiapan, pembahasan dan pengesahan, pengundangan dan penyebarluasan, maupun partisipasi masyarakat. Undang-Undang ini pada dasarnya dimaksudkan untuk membentuk suatu ketentuan yang baku mengenai tata cara Pembentukan Peraturan Perundangundangan, serta untuk memenuhi perintah Pasal 22A Undang-Undang Dasar Negara Republik Indonesia Tahun 1945 dan Pasal 6 Ketetapan Majelis Permusyawaratan Rakyat Nomor III/MPR/2000 Tentang Sumber Hukum dan Tata Urutan Peraturan Perundang-undangan. Namun UndangUndang ini hanya mengatur tentang Pembentukan Peraturan Perundangundangan yang meliputi Undang-Undang/
Peraturan Pemerintah Pengganti Undangundang, Peraturan Pemerintah, Peraturan Presiden, dan Peraturan Daerah. Sedangkan mengenai pembentukan Undang-Undang Dasar tidak diatur dalam Undang-Undang ini. Hal ini karena tidak termasuk kompetensi pembentuk Undang-Undang ke bawah.

Peraturan pelaksana yang baik harus sesuai dengan jenis dan hierarki peraturan perundang-undangan sebagaimana dimaksud dalam Pasal 7 ayat (1) UndangUndang Nomor 12 Tahun 2011, yaitu:

a. Undang-Undang Dasar Negara Republik Indonesia Tahun 1945.

b. Ketetapan Majelis Permuswaratan Rakyat.

c. Undang-Undang/Peraturan Pemerintah Pengganti Undang-Undang.

d. Peraturan Pemerintah.

e. Peraturan Presiden.

f. Peraturan Daerah Provinsi.

g. Peraturan Daerah Kota/Kabupaten.

Rumusan tentang jenis peraturan perundang-undangan tersebut dapat dibedakan menjadi tiga produk hukum utama, yaitu:

a. Undang-Undang Dasar.

b. Undang-Undang.

c. Peraturan.

Dengan klasifikasi tersebut nampak jelas pembentuknya, yaitu:

a. Undang-Undang Dasar sebagai produk Majelis Permusyawaratan Rakyat.

b. Undang-Undang sebagai produk legislasi (Dewan Perwakilan Rakyat bersama Presiden).

c. Peraturan sebagai produk eksekutif dalam rangka regulasi.

Klasifikasi tersebut dengan sendirinya akan berkaitan dengan materi muatan 
dan dengan sendirinya menunjukkan hierarki ${ }^{10}$.

Asas dari peraturan perundangundangan termaktub dalam Bab II Pasal 5 Undang-Undang Nomor 12 Tahun 2011 yang menyatakan bahwa dalam membentuk peraturan perundangundangan harus berdasarkan pada asas pembentukan peraturan perundangundangan yang baik yang meliputi:
a. kejelasan tujuan;
b. kelembagaan atau organ pembentuk yang tepat;
c. kesesuaian antara jenis dan materi muatan;
d. dapat dilaksanakan;
e. kedayagunaan dan kehasilgunaan;
f. kejelasan rumusan; dan
g. keterbukaan.

Materi yang dimuat oleh perundangundangan, harus mencerminkan beberapa asas. Dalam Pasal 6 ayat (1) dijelaskan bahwa materi muatan peraturan perundang-undangan harus didasarkan pada beberapa asas, yaitu:
a. pengayoman;
b. kemanusiaan;
c. kebangsaan;
d. kekeluargaan;
e. kenusantaraan;
f. Bhineka Tunggal Ika;
g. keadilan;
h. kesamaan kedudukan dalam hukum dan pemerintahan;
i. ketertiban dan kepastian hukum; dan/ atau

j. keseimbangan, keserasian, dan keselarasan.

Selain asas sebagaimana dimaksud pada ayat (1), peraturan perundangundangan tertentu dapat berisi asas lain sesuai dengan bidang hukum peraturan perundang-undangan yang bersangkutan. Pada prinsipnya setiap muatan materi perundang-undangan yang dikeluarkan oleh penyelenggara Negara, termasuk Presiden dan Pembantu Presiden, harus merujuk dan berdasarkan prinsip-prinsip yang digambarkan dalam Undang-Undang Dasar 1945.

Asas Pembentukan Peraturan Perundang-undangan yang baik sebagaimana dimaksud dalam UndangUndang Nomor 12 Tahun 2011 tersebut bila dikaitkan dengan Undang-Undang Nomor 17 Tahun 2000 Juncto UndangUndang Nomor 36 Tahun 2008 dan Undang-Undang Nomor 23 Tahun 2011 dapat diuraikan sebagai berikut:

a. Kejelasan tujuan

Pada Undang-Undang Nomor 23 Tahun 2011 dalam Pasal 22, memiliki tujuan agar masyarakat tidak terkena beban berganda yakni kewajiban membayar pajak dan zakat. Sehingga masyarakat lebih sadar dalam membayar zakat. Undang-Undang Nomor 17 Tahun 2000 Juncto Undang-Undang Nomor 36 Tahun 2008 terutama Pasal 9 ayat (1) huruf g dibentuk agar UndangUndang Nomor 23 Tahun 2011 dapat dilaksanakan.

10 Philipus M. Hadjon, Analisis Terhadap UU No. 10 Tahun 2004 Tentang Pembentukan Peraturan Perundang-undangan, dalam Buku Butir-butir Pemikiran dalam Hukum, Memperingati 70 Tahun Prof. Dr. B. Arief Sidharta, SH, Refika Aditama, Bandung, 2008, hlm. 279. 
b. Kelembagaan atau Organ Pembentuk Kelembagaan atau organ pembentuk Undang-Undang berkaitan dengan zakat dapat mengurangi penghasilan kena pajak, telah sesuai. Tetapi yang mungkin harus menjadi perhatian adalah pembentukan peraturan pelaksananya. Hal ini dikarenakan zakat yang dapat mengurangi penghasilan kena pajak berkaitan dengan dua departemen yaitu Departemen Agama dan Departemen Keuangan, sehingga harus terdapat peraturan yang dapat mengatur untuk kedua departemen.

c. Kesesuaian antara jenis dan muatan Materi muatan yang diatur dalam Undang-Undang No. 23 Tahun 2011 dan Undang-Undang No. 17 Tahun 2000 Juncto Undang-Undang No. 36 Tahun 2008, jenis dan muatan undangundang tersebut telah sesuai.

d. Dapat dilaksanakan

Undang-Undang No. 17 Tahun 2000 Juncto Undang-Undang No. 36 Tahun 2008 dan Undang-Undang No. 38 Tahun 1999, masing-masing telah dikeluarkan peraturan pelaksanaannya. Peraturan pelaksana yang ada ternyata belum mampu menjamin dapat dilaksanakan zakat mengurangi penghasilan kena pajak. Zakat yang dapat mengurangi penghasilan kena pajak hanyalah, jika zakat dibayarkan pada BAZ saja tidak pada LAZ.

Ada baiknya peraturan pelaksana Undang-Undang Nomor 23 Tahun 2011 dan Undang-Undang Nomor 17 Tahun 2000 yang kemudian diubah dengan Undang-Undang Nomor 36 Tahun 2008 tentang Perubahan Keempat Atas Undang-Undang Nomor 7 Tahun 1983 tentang Pajak Penghasilan, diatur dalam satu bentuk peraturan yaitu Peraturan Pemerintah. Adapun maksud dari Peraturan Pemerintah tersebut adalah agar masing-masing departemen, yaitu Departemen Keuangan dan Departemen Agama tunduk pada satu peraturan.

Negara Indonesia merupakan negara yang berdasarkan hukum. Pada negara hukum, kekuasaan tidak tanpa batas artinya kekuasaan itu tunduk pada hukum $^{11}$. Suatu negara hukum yang demokratis, dimana kekuasaan tertinggi atau kedaulatan ada di tangan rakyat. Penting pula mempertahankan asasasas yang merupakan pencerminan dari tekad dan aspirasi kita sebagai bangsa, yang mencapai kemerdekaannya dengan perjuangan. Asas-asas tersebut terkandung dalam Undang-Undang Dasar 1945 dan pembukaannya yang merupakan pencerminan dari falsafah Pancasila ${ }^{12}$ :

a. Asas ketuhanan yang mengamanatkan bahwa tidak boleh ada produk hukum nasional yang bertentangan dengan agama atau bersifat menolak atau bermusuhan dengan agama.

b. Asas perikemanusiaan mengamanatkan bahwa hukum harus melindungi warga negara dan menjunjung tinggi martabat manusia.

\footnotetext{
11 Mochtar Kusumaatmadja, B Arief Sidharta, Pengantar Ilmu Hukun Suatu Pengenalan Peranan Ruang Lingkup Berlakunya Ilmu Hukum, Buku I, PT Alumni, Bandung, 2000, hlm. 135.

12 Ibid., hlm. 135.
} 
c. Asas kesatuan dan persatuan atau kebangsaan mengamanatkan bahwa hukum Indonesia harus merupakan hukum nasional yang berlaku bagi seluruh bangsa Indonesia. Hukum nasional berfungsi mempersatukan bangsa Indonesia.

d. Asas demokrasi mengamanatkan bahwa dalam hubungan antara hukum dan kekuasaan, kekuasaan harus tunduk pada hukum, bukan sebaliknya. Pada analisis terakhir kekuasaan ada pada rakyat dan wakil rakyat.

e. Asas keadilan sosial mengamanatkan bahwa semua warga negara mempunyai hak yang sama dan bahwa semua orang sama dihadapan hukum. Penetapan Undang-Undang Nomor 17 Tahun 2000 tentang Perubahan Ketiga Atas Undang-Undang Nomor 7 Tahun 1983 tentang Pajak penghasilan Juncto Undang-Undang Nomor 36 Tahun 2008 tentang Perubahan Keempat Atas Undang-Undang Nomor 7 Tahun 1983 tentang Pajak Penghasilan dan UndangUndang Nomor 38 Tahun 1999 tentang Pengelolaan Zakat, menurut penulis telah mengamalkan salah satu asas yang disebutkan dalam Falsafah Pancasila yaitu Asas Ketuhanan Yang Maha Esa. Produk hukum negara tidak boleh bertentangan dengan agama dan bermusuhan dengan agama. Asas lain yang dipenuhi adalah Asas Keadilan Sosial. Asas keadilan sosial mengamanatkan bahwa semua warga negara mempunyai hak yang sama dan bahwa semua orang sama dihadapan hukum. Pada kedua undang-undang tersebut di atas mengamanatkan, bahwa semua warga negara yang beragama Islam diwajibkan membayar zakat. Pembayaran zakat menurut kedua peraturan tersebut hanya sebagai biaya, karena hanya dapat mengurangi penghasilan kena pajak, tidak mengurangi pajak. Kedua peraturan tersebut ternyata belum memberikan kepastian hukum dalam pelaksanaannya. Meskipun menurut Gustav Radbruch yang dikutip dari buku Pengantar Teori Hukum $^{13}$ ada 3 sendi hukum:
a. keadilan.
b. kegunaan.
c. kepastian hukum.

Ketiga sendi tersebut untuk mencapainya kadang-kadang tidak terpenuhi. Unsur keadilan dan unsur kepastian hukum tidak serta merta menciptakan kepastian hukum. Yang benar dan mutlak adalah bahwa hukum menciptakan kepastian peraturan ${ }^{14}$. Kemudian untuk efektivitas penegakan hukum dibutuhkan 4 unsur pokok:

a. Substansi dari hukum itu

Suatu produk hukum dikatakan baik jika hukum itu mengandung kepastian hukum, dalam arti penjatuhan sanksi serta dapat dilaksanakan oleh masyarakat di samping memberikan kepastian hukum, juga memberikan kemanfaatan artinya para pelanggar akan menjadi sadar.

Bila dikaitkan dengan Undang-Undang Nomor 17 Tahun 2000 Juncto UndangUndang Nomor 36 Tahun 2008

13 Achmad Rustandi, Ibrahim Bachtiar, Pengantar Teori Hukum, Koperasi Mahasiswa Universitas Islam Nusantara, 1988, Bandung, hlm. 20.

14 Satjipto Rahardjo, Biarkan Hukum Mengalir, Catatan Kritis tentang Pergulatan Manusia dan Hukum, PT Kompas Media Nusantara, 2007, Jakarta, hlm. 78. 
khususnya dalam Pasal 9 ayat (1) huruf g, tidak mencantumkan sanksi. Undang-Undang Nomor 38 Tahun 1999 dalam Pasal 14 ayat (3) juga tidak mencantumkan sanksi, apabila tidak melaksanakan kewajibannya. Kewajiban tersebut adalah membayar zakat. Peraturan tersebut di atas dalam implementasi atau pelaksanaannya hanya masih memerlukan peraturan pelaksana yang dibuat antara dua departemen yaitu Departemen Agama dan Departemen Keuangan. Dengan demikian peraturan pelaksana nantinya dapat dilaksanakan pada kedua departemen tersebut.

Denganadanyazakatdapatmengurangi penghasilan kena pajak, diharapkan warga negara yang beragama Islam menjalankan membayar zakat. Dalam peraturan pembayaran zakat yang dapat mengurangi penghasilan kena pajak, peraturan ini mendidik masyarakat agar mau membayar pajak dan membayar zakat. Hal ini sesuai dengan apa yang dikemukakan oleh Mochtar Kusumaatmadja ${ }^{15}$ yaitu hukum sebagai sarana pembaharu. Pada peraturan tersebut di atas dengan dikeluarkannya undang-undang tersebut, diharapkan masyarakat mau membayar zakat dan pajak.

b. Struktur penegakan hukum

Struktur yang dimaksud adalah birokrasi hukum. Pada pembayaran zakat yang dapat mengurangi penghasilan kena pajak, birokrasinya berbelit. Sesuai dengan peraturan pelaksananya yaitu Peraturan Daerah,
Keputusan Walikota dan Keputusan Direktur Jenderal Pajak. Pembayaran zakat menurut peraturan yang ada dilakukan di BAZ atau LAZ. Setelah membayar kemudian melampirkan bukti setor pada saat pengajuan surat pemberitahuan pajak.

c. Masalah fasilitas dan sarana yang dimiliki penegak hukum serba terbatas Fasilitas dan sarana merupakan salah satu unsur yang menunjang penegakan hukum. Penegakan hukum khususnya di bidang zakat dapat mengurangi penghasilan kena pajak, memerlukan peraturan pelaksana sesuai dengan peraturan yang berlaku.

Bila dikaitkan dengan zakat yang dapat mengurangi penghasilan kena pajak, maka dapat dilihat prinsip keadilan berdasarkan Hukum Islam. Prinsip keadilan itu adalah dengan diterapkannya zakat mengurangi penghasilan kena pajak mempunyai hikmah dan tujuan. Hikmah dari zakat yang dilaksanakan dengan benar akan melahirkan dampak positif, diantaranya:

1) Mengikis sifat kikir dan melatih seseorang untuk mempunyai sifat dermawan.

2) Menciptakan ketenangan dan ketentraman bagi pemberi dan penerima zakat.

3) Mendorong untuk terus menerus mengembangkan harta benda.

4) Menciptakan dan memelihara persatuan persaudaraan sesama umat dan menumbuhkan rasa solidaritas.

\footnotetext{
15 Mochtar Kusumaatmdja, Konsep-Konsep Hukum dalam Pembangunan, Op.Cit., hlm. 20.
} 
5) Mensucikan diri dari kotoran dosa, memurnikan jiwa dan menumbuhkan akhlak mulia menjadi murah hati.

6) Menolong, membina dan membangun kaum yang lemah untuk memenuhi kebutuhan pokok hidupnya.

\section{PENUTUP}

Kesimpulan dari analisa yang telah dilakukan antara lain:

1. Cara pembayaran zakat yang dapat mengurangi penghasilan kena pajak dalam Undang-Undang penghasilan pajak adalah zakat yang dibayarkan pada BAZ dan LAZ yang berlaku dapat mengurangi penghasilan kena pajak. Yaitu pembayaran zakat dapat mengurangi penghasilan kena pajak, harus dibayar melalui BAZ atau LAZ. Pembayaran yang dilakukan oleh muzaki harus mendapatkan bukti setor zakat baik dari BAZ dan LAZ. Bukti setor tersebut dapat disertakan pada saat mengirimkan surat pemberitahuan pajak. Bukti setor pajak tersebut harus sesuai dengan peraturan-peraturan yang ada, sehingga dapat mengurangi penghasilan kena pajak. Pembayaran zakat tersebut di atas baru sebatas peraturan saja. Kenyataanya adalah pembayaran zakat yang dapat mengurangi penghasilan kena pajak baru dapat dilaksanakan pada pegawai pemerintahan Kota Bandung yang pembayaran zakatnya dilakukan dengan memotong gaji mereka oleh bendahara kantor. Sedangkan pembayaran zakat pada LAZ tidak dapat mengurangi penghasilan kena pajak, juga karena bukti setor yang berbeda-beda antara yang dikeluarkan oleh Departeman Agama dan Departemen Keuangan.

2. Undang-Undang Nomor 36 Tahun 2008 Tentang Perubahan Keempat Atas Undang-Undang Nomor 7 Tahun 1983 Tentang Pajak Penghasilan belum menjamin pelaksanaan pembayaran zakat yang dapat mengurangi penghasilan kena pajak karena terdapatnya perbedaan dengan Undang-Undang Nomor 23 Tahun 2011 Tentang Pengelolaan Zakat. Salah satu perbedaannya adalah bukti setor zakat yang dibuat tidak seragam sehingga mengakibatkan zakat yang dibayarkan tidak dapat dikurangkan pada pada penghasilan kena pajak. Untuk itu perlu dibuat peraturan pelaksana disesuaikan dengan Undang-Undang Nomor 12 Tahun 2011 Tentang Pembentukan Peraturan Perundangundangan. Peraturan pelaksana seharusnya dibuat dalam bentuk peraturan pemerintah agar semua departeman yang berkaitan tunduk pada satu aturan. Apabila dikaitkan dengan teori yang dikemukakan oleh Muchtar Kusumaatmadja, hukum sebagai alat pembaharu masyarakat. Zakat mengurangi penghasilan kena pajak merupakan hal baru yang dikenal pada masyarakat, dengan diterapkannya hukum tersebut diharapkan masyarakat mau membayar pajak dan zakat. Dengan demikian peraturan harus selangkah lebih maju dalam mengaturnya dan diharapkan peraturan tersebut dapat dilaksanakan. 
3. Hambatan-hambatan yang ada pada saat ini adalah bahwa ternyata pembayaran zakat ternyata belum dapat mengurangi penghasilan kena pajak. Salah satu hambatannya adalah perbedaan bukti setor antara LAZ dan BAZ mengakibatkan pegawai kantor pajak tidak menerima jika pembayaran dilakukan di LAZ. Hambatan yang lain juga adalah tidak adanya sosialisasi mengenai pembayaran zakat yang dapat mengurangi penghasilan kena pajak sehingga mengakibatkan ketidaktahuan dikalangan masyarakat pembayar zakat dan juga dikalangan pegawai Kantor Pelayanan Pajak. Pada kenyataanya pada LAZ "Rumah Zakat" selama ini tidak ada data yang membayar zakat untuk kemudian dikurangkan pada penghasilan kena pajak para wajib pajak Sehingga saat ini peraturan pembayaran zakat yang dapat mengurangi penghasilan kena pajak merupakan peraturan yang hanya memberikan kepastian undangundang saja dan belum memberikan kepastian hukum bagi para pembayar zakat yang ada di Indonesia.

\section{DAFTAR PUSTAKA}

Achmad Rustandi, Ibrahim Bachtiar, Pengantar Teori Hukum, Koperasi Mahasiswa Universitas Islam Nusantara, 1988, Bandung.

Edi Slamet Irianto - Syarifudin Jurdi, Politik Perpajakan Membangun Demokrasi Negara, UII Press, Yogyakarta, 2005.
Mochtar Kusumaatmadja, B Arief Sidharta, Pengantar Ilmu Hukun Suatu Pengenalan Peranan Ruang Lingkup Berlakunya Ilmu Hukum, Buku I, PT Alumni, Bandung, 2000.

Philipus M. Hadjon, Analisis Terhadap UU No.10 Tahun 2004 Tentang Pembentukan Peraturan Perundangundangan, dalam Buku Butir-butir Pemikiran dalam Hukum, Memperingati 70 Tahun Prof. Dr. B.Arief Sidharta, SH, Refika Aditama, Bandung, 2008.

Satjipto Rahardjo, Biarkan Hukum Mengalir, catatan kritis tentang pergulantan manusia dan hukum, Kompas, Jakarta, 2007.

Syofrin Syofyan - Asyhar Hidayat, Hukum Pajak dan Pemasalahannya, PT Refika Aditama, Bandung, 2004.

Yusuf Qardawi, Hukum Zakat, Pustaka Lentera Antar Nusa, terjemahan oleh Salman Harun, Didin Hafiuddin, Hasanudin, 2004. 